\title{
Covid-19 Süresince Psiko-Sosyal Destek Hattında Çalışan Psikologların Psikolojik Sağlamlık Düzeyleri İle Erken Dönem Uyumsuz Şemaları Arasındaki İlişki
}

\section{Relationship Between Psychological Resilience And Early Maladaptive Schemas Of Psychologists Who Worked At Psychological Support Line During Covid-19 Pandemic}

\author{
Şengül Altan Arslan ${ }^{1}$, Mertcan Topal ${ }^{2 *}$ \\ ${ }^{1}$ Dr, İstanbul Büyükșehir Belediyesi, sengul.altanarslan@gmail.com, orcid.org/ 0000-0002-0333-6210 \\ ${ }^{2}$ Uzman, İstanbul Büyükşehir Belediyesi, mrtcn.tp112@gmail.com, orcid.org/0000-0003-3525-9090 , *Sorumlu \\ Yazar
}

Geliş tarihi/Received : 02.08.2021 Kabul tarihi/Accepted: 21.12.2021 Yayın tarihi/Published: 30.12.2021

\section{ÖZET}

Bu çalışmanın amacı Covid-19 pandemi sürecinde psiko-sosyal destek hattında çalışan psikologlarda psikolojik sağlamlık ile erken dönem uyumsuz șemaları arasındaki ilişkiyi incelemektir. Araştırmanın örneklemini, İstanbul Büyükşehir Belediyesi (IBB) Toplum Ruh Sağlığı Hizmetleri kapsamında hizmet veren Psikolojik Danışmanlık Merkezleri ve Psikoterapi Merkezlerinde görev yapan 99 psikolog oluşturmaktadır. Veri toplama aracı olarak; demografik bilgi formu, Young Şema Ölçeği Kısa Form-3 ve Psikolojik Sağlamlık Ölçeği kullanılmıştır. Psikolojik Sağlamlık ve Erken Dönem Uyumsuz Şemalar arasındaki ilişkiyi incelemek için Pearson Korelasyon ve Basit Regresyon analizleri kullanılmıştır. Regresyon analizi için kurulan modelde bağımsız değişken erken dönem uyumsuz şemalar, bağımlı değişken ise psikolojik sağlamlık olarak belirlenmiştir. Araştırmadan elde edilen sonuçların, Psikolojik Sağlamlığın 11 alt şema alanı ile anlamlı bir ilişki gösterdiği, 3 alt şema alanı ile ise anlamlı bir ilişki göstermediği görülmüştür. Araştırmadan elde edilen sonuçlar, Kopukluk ve Zedelenmiş Otonomi alanlarındaki alt şema basamakları, Diğerleri Yönelimlilik alanındaki "Cezalandırma" alt şema basamağı ve Yüksek Standartlar/Bastırılmışlık şema alanındaki "Yüksek Standartlar" alt şema basamağı ile psikolojik sağlamlık arasında negatif yönde anlamlı ilişki olduğunu göstermiştir. Bu araştırma sonucunda ortaya çıkan bulguların IBB tarafından sunulan toplum ruh sağlığı hizmetlerinin geliştirilmesine ve meslek elemanlarına yönelik yapılacak hizmetiçi eğitimlerin önceliğinin belirlenmesi, ayrıca yapılacak çalışmalara yön vermesi hedeflenmektedir.

Anahtar Kelimeler: Erken Dönem Uyumsuz Şemalar, Psikolojik Sağlamlık, Covid-19

\begin{abstract}
The purpose of this study was to examine the relationship between early maladaptive schemas and psychological resilience of psychologist who worked at psychosocial support line during covid-19 pandemic. The sample of the study consists of 99 psychologists working in the Psychological Counseling Centers and Psychotherapy Centers serving the Istanbul Metropolitan Municipality Community Mental Health Services. Demographic information form, Young Schema Questionaire- Short Form 3 and Psychological Resilience Scale were used to collect data. Relationships between variables were examined by regression analysis and simple correlation analysis. Results revealed that there was a significant relationship between 'Disconnection/Rejection', 'schema domains', 'Impaired Autonomy', 'schema domains', 'Punitiveness', 'Unrelenting Standards' and psychological resilience. This study aims to develop mental health services at the IBB and determine the priority or in-service training for psychologists.
\end{abstract}

Keywords: Early maladaptive schemas, Psychological Resilience, Covid-19 


\section{GíRIŞ}

Bireylerin mevcut problem çözme ve baş etme becerilerinin yetersiz kaldığ 1 , aniden gelişerek bireyin tüm dengelerini sarsan etkilerinin olduğu durumlar kriz olarak tanımlanabilmektedir (Roberts, 2005). Kriz sonrası sarsılan dengenin yeniden kurulması ve krizin atlatılması, krizin şiddeti ile orantılı olarak zaman alır ve bireysel farklılıklara göre zorlayıcı olabilmektedir. Dünyada daha önce aniden ortaya çıkan ve tüm sistemleri derinden etkileyen AIDS, SARS H1N1 (kuş gribi) gibi salgın hastalıklar, bireylerin ve toplumların etkilenmesine yol açmıştır. Bu salgınların en yenisi ise 2019'un Aralık ayında Çin'in Wuhan kentinde ortaya çıkan Covid19 salgınıdır. Dünyada ve ülkemizde birçok ölüme sebep olan salgın tüm dünyayı etkisine alarak beden ve ruh sağlığını olumsuz yönde etkilediği ve önemli bir stres kaynağı haline geldiği görülmektedir. Ortaya çıkan bu salgını tinsel, bilişsel, sosyal, fiziksel ve psikolojik olarak ele almak ve tüm gelişim aşamalarına etkisini ortaya koymak gerekmektedir. Covid-19 salgını süresince salgın sürecindeki belirsizlik, karantina uygulamaları, çalışma yaşamında gerçekleşen iş kayıpları ve yeni çalışma modellerinin ortaya çıkması depresyon ve kaygı düzeylerini arttırmaktadır. Yaşanan bu süreç bireylerin olumsuz duygu durumlarının artmasına, olumlu duygu durumlarının ise azalmasına sebep olmaktadır.

Ortaya çıkan buna benzer krizlerde bireyler kendilerini yoğun stres altında hissedebilirler. Stres faktörlerine karşın bireyin strese verdiği tepkiler daha önceki yaşam deneyimleri ve stresi algılama biçimlerine göre değişkenlik göstermektedir. Gerçekleştirilen araştırmalarda SARS salgınında bireylerde travma sonrası stres bozukluğu görülme oranı oldukça yüksektir (Liu ve diğerleri, 2020). Bu çerçevede yaşanan stres olayları bazı bireylerde psikopatoloji gibi uzun vadede oluşan olumsuz sonuçlara sebep olurken, bazı bireylerde ise psikopatoloji geliştirmez ya da bireyler olaylardan etkilenmeyerek strese karşı uyum sağlayarak yaşam standartlarını koruyabilmektedirler (Dulmus ve Hilarski,2003; Huber, Knottnerus ve Green, 2011). Pandemi sürecinde yaşanan bu durumlarda bireylerin pandemiye karşı verdikleri tepkilerin ve süreçle nasıl başa çıktıklarının anlaşılması büyük önem taşımaktadır (Arden ve Chilot, 2020). Bireylerde ortaya çıkan bu farklılığı açıklayacak en etkili kavram, esneklik olarak da çevrilen, psikolojik sağlamlık 'resilience' terimidir (Bilge ve Bilge, 2020).

Amerikan Psikologlar Birliği (American Psychological Association) (2014) sağlamlığı; bireylerin zorluklara, travmaya veya diğer stres kaynaklarına uyum sağlama süreci olarak tanımlamıştır. Psikolojik sağlamlık, bireyin yaşam boyu karşılaştığı zor koşullara rağmen bu olay/olgulara karşı başarı ve uyum sağlama yeteneğidir (Vella ve Pai, 2019). Sağlamlık, psikolojik bir nitelik olarak tanımlanmakla birlikte bireyin psiko-sosyal boyuttaki sağlıklı gelişimini sürdürmesine katkıda bulunarak, olumsuz bir durumla karşılaşıldığında o duruma karşı mücadele göstermeyi ortaya koymaktır (Dulmus ve Hilarski,2003). Bu sağlamlık bireyin yaşadığı travma, stres ya da kaygı düzeylerini belirli sınırlar içerisine almaz ya da bu durumu tamamen ortadan kaldırmaz. Psikolojik Sağlamlık düzeyi bireyin bu olaylara karşı çözüm üretme ve problemle başa çıkma kapasitelerini arttırarak bu olaylarla birlikte sağlıklı gelişim alanlarının ortaya çıkmasını sağlar ve yaşam akışını sürdürür.

Psikolojik sağlamlık, strese yanıt olarak çok boyutlu, karmaşık ve dinamik bir yapıdır (Kent, Davis ve Reich, 2013). Ayrıca, çoğu araştırmacı, sürecin kendisi içinde, cinsiyet, yaş, sosyokültürel yap1 gibi geniş bir faktör yelpazesinin etkileşiminin bir bireyin dayanıklılık gösterip göstermediğini belirlediğini kabul eder. Bununla birlikte, spesifik açıklama potansiyeli açısından, cinsiyet, yaş, sosyo-kültürel yapı gibi geniş faktörlere yapılan vurgu genellikle değişiklik gösterir (Fletcher ve Sarkar, 2013). Psikolojik sağlamlığın oluşmasının temel koşulu risktir. Bireyin psikolojik sağlamlığının gelişiminde, karşılaşılan risklerin ve riskin getirdiği diğer faktörlerin bireye ve ait olduğu sisteme negatif etkilerinin azaltılmasında ya da ortadan kaldırılmasında, koruyucu faktörler önemli bir rol oynamaktadır (Öz ve Yılmaz,2009). Risk 
faktörleri, istenmeyen, normatif olmayan gelişimsel sonuçların olumsuz değişiklik veya kalıcı değişiklik meydana getiren nedenleridir. Risk faktörleri, bireylerin, kişiler arası ilişkiler, bağlantılar ve diğer kurumsal sistemlerin ölçülebilir özellikleri veya nitelikleridir (Keyes, 2009).

Gelişim dönemlerini göz önünde bulundurduğumuzda, çocukluk ya da ergenlik döneminde risk durumlarıyla karşılaşılması diğer gelişim dönemlerinde farklı sorunlarla karşılaşılmasına ya da sağlıklı gelişim gösterilmemesine sebep olabilmektedir. Bonanno vd. (2007)'ne göre, her bireyin hayatında bir travma ile karşılaşma potansiyeli vardır ve bu travmaların getirdiği yıkıcı etkiler bireyin psikolojik açıdan sağlıklı bir gelişim göstermesinde, aynı zamanda psikolojik sağlamlık sergilemesinde risk unsurları oluşturur. Sahip olduğu sistemlerle ele alındığında birey mikro (kronik rahatsızlık, olumsuz yaşam deneyimleri vb.),mezzo (aile ilişkileri, aile psikopatolojisi vb.) ve makro (afetler, toplumsal olaylar, yoksulluk vb.) boyutlarda risk faktörleri ile karşı karşıya kalmaktadır. Rutter (2006), uzun süreli uyumlu ilişkilerin olmamasının, sosyal gruplar içinde sosyal uyum eksikliğinin ve öğrenme firsatlarının (karşılıklı konuşma alışverişinin yetersiz olması, oyunların olmaması vb.) olmayışının en sık riskli deneyim kaynakları olduğunu düşünmektedir. Risk faktörlerine bakıldığında, bireyin sahip olduğu sistemleri sağlıklı ve olumlu gelişim gösteriyorsa kişinin gelişimine olumlu yönde etki ettiği görülmektedir. Bunun yanı sıra ilgili sistemler bireyi olumsuz yönde etkilerse bireyde ruhsal sorunlar görülme olasılığı artmakta ve psikolojik sağlamlık düzeyi azalmaktadır. $\mathrm{Bu}$ çerçevede risk faktörlerine karşın koruyucu faktörlerin bilinmesi benzer önemli bir noktadır. Bireyin karşılaştı̆̆ zorlukların üstesinden gelememesi ve uyumsuz davranış örüntüleri sergilemesi sonucunda, yardıma ihtiyaç duyması halinde, bireyin psikolojik sağlamlığının güçlendirilmesi gerekmektedir (Öz ve Yılmaz,2009).

Bireyin geçmiş yaşantısı ile problem çözme ve baş etme becerileri arasında bir bağ vardır. Kişiler geçmiş yaşam öğretileri sonucunda problem ya da krizlere karşı, savunma mekanizmalarını harekete geçirerek çözüm yolları arar ya da tepki verirler. Bu çerçevede erken dönem uyumsuz şemaların önemi büyüktür. Erken dönem uyumsuz şemalar, bireyin ilk yaşam deneyimleri ile oluşan, geçmiş yaşam dönemlerinin kalıntılarını içeren ve gelecek dönemdeki yaşam deneyimlerinde bireylere yol haritası oluşturan bilişsel yapılar olarak ortaya konabilir. $\mathrm{Bu}$ yapılar, oluşmaya başladığı andan itibaren bireyin olumsuz yaşam deneyimlerinin üstesinden gelmesine yardımcı olmaktadır (Young, Klosko ve Weishaar, 2003). Bu şemalar, diğer benzer durumlarda da aktive olarak kaygı ve depresyona yol açar (Calvete, Orue ve Hankin, 2015; Cámara ve Calvete, 2011; Lumley ve Harkness, 2007). Bununla birlikte, erken uyumsuz şemalar ile anksiyete ve depresyon belirtileri arasındaki ilişki basit doğrusal bir ilişki gibi görünmemektedir. Çünkü; farklı kişilik özelliklerine sahip çoğu birey, stresli durumlarla yüzleşmede psikolojik belirti göstermez. Başka bir deyişle spesifik belirti göstermeyen bireyler strese karşı dirençlidir (Calvete, Orue ve Hankin, 2015).

Erken dönem uyumsuz şemalar; kim olduğumuza, başkalarıyla ve dünyayla ilişkilerde neler bekleyebileceğimize dair koşulsuz inançları içerirler. Erken çocukluk ve ergenlik döneminde gelişim gösterdiklerinden dolayı kendi kendine devam eder, değişime karşı direnç gösterir ve geleceği tahmin etmeye çalışırlar (Young ve Klosko, 2013). Şemalar, insanların kendileri ile dünya arasındaki etkileşimlere dair bilgilerini düzenlemeye yardımcı olur. Temelde şemalar, her ilişkinin her koşulunda ne olacağını belirleme çabalarıdır. Bu inançlar kişinin geleceğe bakıp ona nasıl hazırlanabileceği hakkında farklı algılama biçimi sunduğundan, vazgeçilmeleri son derece zordur. Bu sebeplerle bireyin sahip olduğu şemalar çok güçlüdür. Erken dönem uyumsuz şemaların gelişimini ortaya koymak ve açıklamak için ergenlik ya da yetişkinlik dönemlerinin geçmişe dönük olarak değerlendirilmesi gerekmektedir. Alan yazında yapılan araştırmalar göz önünde bulundurulduğunda kişilerin içsel modellerinin bazı unsurlarının (bağlanma, öz saygı vb.) erken dönem uyumsuz şemaların gelişimiyle ilişkili olduğunu ortaya 
konmuştur (Young ve Klosko, 2013). Erken dönem uyumsuz şemaların gelişiminde rol oynayan diğer bir faktör de çocuğun duygusal mizacıdır (Gör, Yiğit, Kömürcü ve Şenkal Ertürk, 2017). Alt şema basamaklarının temeline inildiğinde uyumsuz şemaların, bireyin yaşamın erken dönemlerinde çevre alt sistemleri ve ebeveyn alt sistemleri ile yaşadığı travmatize yaşam olaylarının varlığıyla ilişkili olduğu görülmektedir (Adıgüzel, Bapoğlu Dümenci ve Topal, 2019).

Çalışma yaşamları boyunca farklı yaşam deneyimlerine ve travmatik olaylarla karşılaşan ruh sağlığı çalışanlarının stresi nasıl algıladıkları, soruna karşı problem çözme ve başetme becerileri ve olaylara verdikleri tepkiler öncelikle kişilik yapılarına, yani erken dönem uyumsuz şemalarına bağlıdır. Bununla birlikte, ruh sağlığ çalışanlarının bu strese nasıl tepki vereceği kişilik özelliklerinin yanı sıra psikolojik sağlamlık düzeylerine de bağlıdır (Kavi ve Karakale, 2018). Dolayısıyla, bireylerin olumlu nitelikleri ve olaylar karşısında aktif rolleri, stres ve travmatik olaylarla nasıl yüzleştiklerini, yine olaylar karşısında stres veya depresyon gibi ruhsal bozukluklar geliştirip geliştirmediklerini etkilemektedir (Khademi ve Sabbaghi,2017).

2020 yılında Dünya Sağlık Örgütü tarafından 'Pandemi' olarak tanımlanan Covid-19 virüsü tüm dünyayı etkisine alarak bireyleri ve toplumları yaşamsal bir krize sebep olmuştur. Covid19 sürecinde toplumun virüse yakalanma riskinde olması, pandemi sürecinin ne zaman sonlanacağının bilinmemesi, ilk dönemlerde aşının bulunamaması ve her geçen gün artan vaka sayıları; süreç içerisinde yaşanabilecek olumsuz sosyo-ekonomik durumlara karşı belirsizlik bireylerin yoğun stres ve kaygı yaşamalarına sebep olmuştur (MEB, 2020). Süreç içerisinde yaşanan bu durumlardan her bireyin gösterdiği reaksiyonda farklılık göstermektedir. Covid-19 sürecinde yaşanan tüm olay ve olgular psikolojik sağlamlık düzeyi için risk faktörüdür. Son dönemlerde ruh sağlığı alanında yapılan çalışmalarda olumsuz yaşam deneyimlerine ve şartlarına karşın problem çözme ve baş etme becerilerine yönelik araştırmalar artmıştır (Traş ve Aydın, 2019). Süreçte yaşanan olumsuz durumlar bireylerin psikolojik sağlamlık düzeylerine karşı tehdit oluşturmaktadır. Alan yazına bakıldığında bu süreçte insanların fiziksel sağlıklarına da etki eden ruhsal sağlıklarını korumaları için psikolojik sağlamlık düzeylerini yüksek tutmaları gerekliliği ortaya çıkmaktadır. Tüm dünyada Mart 2020 tarihinden itibaren gerek psiko-sosyal gerekse sosyo-ekonomik alanlarda birçok çalışma yürütülmüştür (Bilge ve Bilge, 2020; Kimter, 2020; Killgore, Taylor ve Cloonan, 2020). Pandemi süreci toplumun tüm kesimlerini olumsuz olarak etkilemiştir. İstanbul Büyükşehir Belediyesi (İBB) bünyesinde 'Toplum Ruh Sağlı̆̆ı' hizmetleri kapsamında yer alan Psikolojik Danışmanlık Merkezleri ve Psikoterapi Merkezlerinde görevli ruh sağlığ 1 çalışanları da, ortaya çıkan bu kriz çerçevesinde, toplumun tüm yönlerini derinden etkileyen pandemiye karşı gerekli önlemleri alarak toplumun ihtiyaçlarını karşılayan psiko-sosyal destek çalışmalarına hız vermiştir. Bu çerçevede, toplum ruh sağlı̆̆ profesyonellerinin toplumun gösterdiği psikolojik tepkilerin sağlıklı yönde evrilmesi, psiko-sosyal tepkilerin ölçülmesi, bireylerin ve aynı zamanda toplumun ruh sağlığının korunması için önemli çalışmalarda bulunmaları beklenmektedir.

$\mathrm{Bu}$ araştırmanın amacı, Covid-19 pandemi sürecinde psiko-sosyal destek hattında çalışan psikologlarda psikolojik sağlamlık ile erken dönem uyumsuz şemaları arasındaki ilişkiyi incelemektir. Araştırma ana amacı doğrultusunda aşağıdaki sorulara cevap aranmıştır;

-Sosyo-Demografik özellikler ile psikolojik sağlamlık düzeyi arasında anlamlı bir farklılık var midir?

-Erken dönem uyumsuz şema alt basamakları ile psikolojik sağlamlık düzeyi arasında ilişki var midir?

- Erken dönem uyumsuz şema alt basamakları bireyin sahip olduğu psikolojik sağlamlık düzeyini yordamakta mıdır? 


\section{YÖNTEM}

\section{Araştırma Modeli}

$\mathrm{Bu}$ araştırmada, nicel araştırma yöntemlerimden ilişkisel tarama modeli kullanılmıştır.

\section{Çalışma Grubu}

Araştırma evreni, İBB Sağlık Hıfzıssıhha Müdürlüğü tarafından sağlanan ‘Toplum Ruh Sağlığ1 Hizmeti' kapsamında görev yapan ruh sağlı̆̆ profesyonelleridir. Araştırma Covid-19 sürecinde Psiko-sosyal destek için kurulan destek hattında çalışan 99 ruh sağlı̆̆ profesyoneli ile gerçekleştirilmiştir.

Tablo 1: Çalışma Grubunun Demografik Dağılımı

\begin{tabular}{llll}
\hline Değişken & Alt Grup & $\mathrm{f}$ & $\%$ \\
\hline \multirow{2}{*}{ Cinsiyet } & Kadın & 85 & 85,86 \\
& Erkek & 14 & 14,14 \\
\hline \multirow{2}{*}{ Medeni Durum } & Bekar & 50 & 50,51 \\
& Evli & 49 & 49,49 \\
\hline \multirow{2}{*}{ Önceden } & Hayır & 74 & 74,75 \\
Çalışma & Evet & 25 & 25,25 \\
\hline \multirow{4}{*}{ Doğum sırası } & 1. & 53 & 53,54 \\
& 2. & 23 & 23,23 \\
& 3. & 15 & 15,15 \\
& 4. & 8 & 8,08 \\
\hline \multirow{2}{*}{ Yaş } & $25-29$ aras1 & 46 & 46,46 \\
& $30-34$ aras1 & 41 & 41,41 \\
Toplam & $35-45$ arası & 12 & 12,12 \\
\hline
\end{tabular}

Tablo 1'de görüldüğü gibi; katılımcıların \%85,86's1 (85) kadın, \%14,14'ü (14) erkektir. Yüzde 50,51'i (50) bekar, \%49,49'u (49) evlidir. Yüzde 74,75'i (74) önceden çalışmadığını, \%25,25'i (25) önceden çalıştığını bildirmiştir. Yüzde 53,54'ü (53) 1.çocuk, \% 23,23'ü (23) 2.çocuk, $\% 15,15$ 'i (15) 3. Çocuk ve \%8,08'i (8) 4.çocuk olduğunu bildirmiştir. Yüzde 46,46'sı (46) 2529 yaş arasında, \%41,41'i (41) 230-34 yaş arasında ve \%12,12'si (12) 35-45 arasındadır.

\section{Veri Toplama Araçları}

Sosyo-Demografik Form: Araştırmacılar tarafından öncelikle araştırmaya gönüllü olarak katıldıkları onam formu ve cinsiyet, yaş, eğitim durumu gibi sosyo-demografik özelliklerine yönelik 12 sorudan oluşan form hazırlanmıştır.

Young Şema Ölçeği (YŞÖ-KF3) : Young (1994) tarafindan oluşturulan erken dönem uyumsuz şemaları değerlendirmek amacıyla oluşturulan ölçek 90 maddeden oluşmaktadır. 90 maddeden oluşan ölçekte katılımcılar, her bir maddeyi altı likert üzerinde (1=Benim için tamamıyla yanlış, 6= Beni mükemmel şekilde tanımlıyor) derecelendirmektedir. Ölçeğin özgün formunda her alt ölçek beş maddeden oluşmakta, buna göre alt ölçeklerden alınan puanlar 5 ile 30 arasında 
değişebilmektedir. YŞÖ-KF3'ün, alt ölçeklerdeki soru sayıları farklı olmasından dolayı alt ölçeklerin puanlarının kıyaslanmasını kolaylaştırmak amacıyla her ölçekteki maddelerin puan toplamları madde sayısına bölünmüştür (Soygüt, Karaosmanoğlu ve Çakır, 2009). Bu işlem araştırma sonuçlarına etki eden bir tercih değildir. Yapılan çalışmalar sonucunda ölçeğin geçerli ve kabul edilebilir düzeyde olduğunu ortaya koymuştur.

YŞÖ-KF3'ün Türkçe gerçerlik güvenilirlik çalışması Soygüt, Karaosmanoğlu ve Çakır (2009) tarafından üniversite örneklemiyle gerçekleştirilmiştir. Yapı geçerliğine ilişkin temel bileşenler analizi sonucu 14 faktörlü yapıya işaret etmekte ve ölçeğin alt ölçeklerinin iç tutarlılık katsayıları ise .54 ile .85 arasında, alt ölçeklerinin iç tutarlılık katsayıları ise .54 ile .85 arasında değişmektedir (Soygüt, Karaosmanoğlu ve Çakır, 2009). Bu araştırma kapsamında YŞÖKF3'ün iç tutarlılık göstergesi olan Cronbach's Alpha değeri .97 olarak tespit edilerek verilerin güvenilir olduğu kabul edilmiştir.

Kısa Psikolojik Sağlamlık Ölçeği (KPSÖ): Smith ve ark (2008) tarafından geliştirilen ve Doğan (2015) tarafından Türkçe geçerlilik güvenirlik çalışması yapılan KPSÖ 6 maddeden oluşan öz bildirim tarzına dayanmaktadır. Ölçekteki altı maddenin üçü ters puanlanmaktadır. Ölçekten alınan puanlar 6 ile 30 arasında değişmektedir. 6-11 puan arası düşük düzeyde psikolojik sağlamlığı, 12-22 puan arası orta düzeyde psikolojik sağlamlığ 1 ve 23-30 arası puan yüksek düzeyde psikolojik sağlamlığı ifade etmektedir. Türk kültürüne uyarlanan ölçeğin doğrulayıcı faktör analizi sonucu elde edilen değerleri, ölçeğin yeterli geçerlilikte olduğunu göstermektedir $(\chi 2 / \mathrm{df}(12.86 / 7)=1,83, \mathrm{NFI}=0.99, \mathrm{CFI}=0.99, \mathrm{GFI}=0.99, \mathrm{SRMR}=0.03, \mathrm{RMSEA}=0.05)$ ve yapılan geçerlilik çalışmasında güvenirlik katsayısı .80 ile .91 arasında değişen değerlerde bulunmuştur. Bu araştırma kapsamında altı sorudan oluşan Psikolojik Sağlamlık Ölçeğinin Cronbach's Alpha değeri .79 olarak tespit edilerek verilerin güvenilir olduğu kabul edilmiştir.

\section{Verilerin Toplanması ve Analizi}

Veriler, Covid-19 süresi boyunca psiko-sosyal destek hattında çalışan ruh sağlı̆̆1 personellerinden, gönüllülük esasına göre, pandemi sürecinde göz önünde bulundurularak, çevrimiçi ortamda toplanmıştır. Araştırmada kullanılan ölçekler Google Forms ile 3 basamaktan oluşturulmuş ve araştırma linki e-mail/whatsapp aracılığı ile iletilmiştir. Veri toplama süreci yaklaşık olarak $40 \mathrm{dk}$ sürmüştür. Araştırma verilerinin kullanılarak bilimsel alanda yayınlanmasına ilişkin izin gerekli birimden alınmıştır.

Elde edilen veriler çerçevesinde SPSS 24 paket programı kullanılarak analiz edilmiştir. Verin analizine geçmeden önce normalliği sınanmıştır. Bu araştırmada verilerin normal dağıldığ sonucuna çarpıklık ve basıklık katsayılarının -3 ile +3 arasında olmasının yeterli olacağına dair (Groeneveld ve Meeden, 1984; Moors, 1986; De Carlo, 1997; George ve Mallery, 2010; Örücü ve Boz, 2014) görüşler referans alınarak varılmıştır. Psikolojik Sağlamlık Ölçek verilerinin çarpıklığ1 -0,24 basıklığ1 1,94; Young Şema Ölçek verinin çarpıklığı 0,61 ve basıklı̆̆ $-0,45$ ile aranan referans aralıklarında olduğundan veri dağılımının normalliğine hükmedilmiş ve araştırmada parametrik testlerin kullanılmasına karar verilmiştir. Araştırma verilerine ilişkin olarak t tesit, tek yönlü ANOVA, basit regresyon, Pearson Korelasyon testleri uygulanmıştır. 


\section{BULGULAR}

Tablo 2: Psikolojik Sağlamlığın Cinsiyete Göre Farklılaşması

\begin{tabular}{lllllllll} 
Cinsiyet & $\mathrm{N}$ & $\mathrm{X}$ & $\mathrm{SS}$ & $\mathrm{F}$ & $\mathrm{p}$ & $\mathrm{t}$ & $\mathrm{sd}$ & $\mathrm{p}$ \\
\hline Kadın & 85 & 21,87 & 4,03 & 2,24 & 0,138 & $-0,24$ & 97,00 & 0,807 \\
Erkek & 14 & 22,14 & 2,48 & & & & & \\
\hline
\end{tabular}

Tablo 2'de görüldüğü gibi, 'psikolojik sağlamlığın cinsiyete göre farklılaşması' sınaması için yapılan bağımsız gruplar $\mathrm{t}$ testi sonucunda, erkekler lehine tespit edilen farklılaşma istatistiksel olarak anlamlı bulunmamıştır $(\mathrm{p}=0,807 ; \mathrm{t}=-0,24)$.

Tablo 3: Psikolojik Sağlamlığın Medeni Duruma Göre Farklılaşması

\begin{tabular}{lllllllll}
$\begin{array}{l}\text { Medeni } \\
\text { Durum }\end{array}$ & $\mathrm{N}$ & $\mathrm{X}$ & $\mathrm{SS}$ & $\mathrm{F}$ & $\mathrm{p}$ & $\mathrm{t}$ & $\mathrm{sd}$ & $\mathrm{p}$ \\
\hline Bekar & 50 & 20,68 & 3,69 & 0,09 & 0,771 & $-3,39$ & 97,00 & 0,001 \\
Evli & 49 & 23,16 & 3,60 & & & & & \\
\hline
\end{tabular}

Tablo 3’te görüldüğü gibi, ‘psikolojik sağlamlığın medeni duruma göre farklılaşması' sınaması için yapılan bağımsız gruplar t testi sonucunda, evliler lehine tespit edilen farklılaşma istatistiksel olarak $\mathrm{p}<0,01$ düzeyinde anlamlı bulunmuştur $(\mathrm{p}=0,001 ; \mathrm{t}=-3,39)$.

Tablo 4: Psikolojik Sağlamlığın Önceden Çalışmış Olma Durumuna Göre Farklılaşması

\begin{tabular}{lllllllll}
\hline $\begin{array}{l}\text { Önceden } \\
\text { çalışma } \\
\text { durumu }\end{array}$ & $\mathrm{N}$ & $\mathrm{X}$ & $\mathrm{SS}$ & $\mathrm{F}$ & $\mathrm{p}$ & $\mathrm{t}$ & $\mathrm{sd}$ & $\mathrm{p}$ \\
\hline Hayır & 74 & 21,96 & 4,08 & 0,85 & 0,358 & 0,22 & 97,00 & 0,823 \\
Evet & 25 & 21,76 & 3,07 & & & & & \\
\hline
\end{tabular}

Tablo 4'te görüldüğü gibi, 'psikolojik sağlamlığın önceden bir işte çalışmış olma durumuna göre farklılaşması' sınaması için yapılan bağımsız gruplar t testi sonucunda, önceden çalışmamış olanlar lehine tespit edilen farklılaşma istatistiksel olarak anlamlı bulunmamıştır $(\mathrm{p}=0,823 ; \mathrm{t}=0,22)$.

Tablo 5: Psikolojik Sağlamlığın Yaşa Göre Farklılaşması

\begin{tabular}{llllllllll}
\hline Yaş & $\mathrm{N}$ & $\mathrm{X}$ & $\mathrm{Ss}$ & Var.K & $\mathrm{KT}$ & $\mathrm{Sd}$ & $\mathrm{KO}$ & $\mathrm{F}$ & $\mathrm{p}$ \\
\hline 25-29 aras1 & 46 & 21,46 & 3,30 & G.İçi & 17,61 & 2,00 & 8,81 & 0,59 & 0,554 \\
30-34 aras1 & 41 & 22,29 & 4,35 & G.Aras1 & 1424,57 & 96,00 & 14,84 & & \\
35-45 aras1 & 12 & 22,33 & 4,01 & Toplam & 1442,18 & 98,00 & & & \\
Toplam & 99 & 21,91 & 3,84 & & & & & & \\
\hline
\end{tabular}


Tablo 5'de görüldüğü gibi, 'psikolojik sağlamlığın yaşa göre farklılaşması' sınaması için yapılan Anova testi sonucunda, yaş grupları arasındaki farklılaşmalar istatistiksel olarak anlamlı bulunmamıştır ( $\mathrm{p}=0,554 ; \mathrm{F}=0,59)$.

Tablo 6: Psikolojik Sağlamlığın Doğum Sırasına Göre Farklılaşması

\begin{tabular}{llllllllll} 
Çocukluk Sirasi & $\mathrm{N}$ & $\mathrm{X}$ & $\mathrm{Ss}$ & Var.K & $\mathrm{KT}$ & $\mathrm{Sd}$ & $\mathrm{KO}$ & $\mathrm{F}$ & $\mathrm{p}$ \\
\hline 1. & 53 & 22,09 & 4,54 & G.İçi & 19,55 & 3,00 & 6,52 & 0,44 & 0,728 \\
2. & 23 & 21,30 & 2,42 & G.Aras & 1422,63 & 95,00 & 14,98 & & \\
3. & 15 & 22,53 & 3,58 & Toplam & 1442,18 & 98,00 & & & \\
4. & 8 & 21,25 & 2,43 & & & & & & \\
Toplam & 99 & 21,91 & 3,84 & & & & & & \\
\hline
\end{tabular}

Tablo 6'da görüldüğü gibi, ‘psikolojik sağlamlığın doğum sırasına göre farklılaşması' sınaması için yapılan Anova testi sonucunda, çocukluk sırası grupları arasındaki farklılaşmalar istatistiksel olarak anlamlı bulunmamıştır $(\mathrm{p}=0,728 ; \mathrm{F}=0,44)$.

Psikolojik Sağlamlı̆̆ın Uyumsuz Şemalar İle İlişkisi

Tablo 7: Değişkenler Arası Korelatif İlişkiler (Pearson Korelasyon)

\begin{tabular}{|c|c|c|c|}
\hline \multicolumn{2}{|l|}{ Young Şema Ölçeği } & \multirow{2}{*}{$\begin{array}{l}\text { Psikolojik } \\
(\mathrm{PS}) \\
\mathrm{r}\end{array}$} & \multirow{2}{*}{$\begin{array}{l}\text { Sağlamlik } \\
\mathrm{p} \\
\end{array}$} \\
\hline Üst Şema Alanı & Alt Ölçek & & \\
\hline \multirow{4}{*}{ 1.Kopukluk Şema Alanı } & 1.Duygusal Yoksunluk &,$- 342^{* *}$ & 0,001 \\
\hline & 2.Duyguları Bastırma &,$- 323^{* *}$ & 0,001 \\
\hline & 3.Sosyal İzolasyon/Güvensizlik &,$- 333^{* *}$ & 0,001 \\
\hline & 4.Kusurluluk &,$- 469^{* *}$ & 0,000 \\
\hline \multirow{5}{*}{$\begin{array}{l}\text { 2.Zedelenmiş Otonomi } \\
\text { Şema Alanı }\end{array}$} & 5.İç İçe Geçme/Bağımlılık &,$- 315^{* *}$ & 0,001 \\
\hline & 6. Terk Edilme &,$- 254^{*}$ & 0,011 \\
\hline & 7.Başarısızlık &,$- 496^{* *}$ & 0,000 \\
\hline & 8.Karamsarlık &,$- 319^{* *}$ & 0,001 \\
\hline & 9.Tehditler Karşısında Dayanıksızlık &,$- 451^{* *}$ & 0,000 \\
\hline $\begin{array}{l}\text { 3.Zedelenmiş Sınırlar } \\
\text { Şema Alanı }\end{array}$ & 10.Ayrıcalıklılık/Yetersiz Özdenetim & $-0,116$ & 0,253 \\
\hline \multirow{2}{*}{$\begin{array}{l}\text { 4.Diğerleri Yönelimlilik } \\
\text { Şema Alanı }\end{array}$} & 11.Kendini Feda & $-0,048$ & 0,635 \\
\hline & 12.Cezalandırılma &,$- 232^{*}$ & 0,021 \\
\hline \multirow{2}{*}{$\begin{array}{l}\text { 5.Yüksek Standartlar ve } \\
\text { Bastırılmışlık Şema } \\
\text { Alanı }\end{array}$} & 13.Yüksek Standartlar &,$- 230^{*}$ & 0,022 \\
\hline & 14.Onay Arayıcilık & $-0,082$ & 0,418 \\
\hline
\end{tabular}

Tablo 7'de görüldüğü gibi, Psikolojik Sağlamlığın Erken Dönem Uyumsuz Şemalar ile İlişkisini sınamak için yapılan 'Pearson Korelasyon' analizi sonucunda şu bulgulara ulaşılmıştır:

Psikolojik Sağlamlığın 1.Kopukluk Şema Alanı alt ölçeklerinden 1.Duygusal Yoksunlukla (r= ,342**; $\mathrm{p}=0,001)$, 2.Duygular1 Bastırmamayla $\left(\mathrm{r}=-, 323^{* *} ; \quad \mathrm{p}=0,001\right), \quad$ 3.Sosyal İzolasyon/Güvensizlikle ( $\left.r=-, 333^{* *} ; \mathrm{p}=0,001\right)$ ve 4. Kusurlulukla $\left.\left(r=-, 469^{* *} ;\right) \mathrm{p}=0,000\right)$ negatif 
yönlü ilişkileri anlamlıdır. Psikolojik Sağlamlığın 2.Zedelenmiş Otonomi Şema Alanı alt ölçeklerinden 5.İç İçe Geçme/Bağımlılıkla ( $\left.\mathrm{r}=-, 315^{* *} ; \mathrm{p}=0,001\right)$, 6.Terk Edilmeyle $\left(\mathrm{r}=-, 254^{*}\right.$; $\mathrm{p}=0,011)$, 7.Başarısızlıkla $\left(\mathrm{r}=-, 496^{* *} ; \mathrm{p}=0,000\right)$, 8.Karamsarlıkla $\left(\mathrm{r}=-, 319^{* *} ; \mathrm{p}=0,001\right)$ ve 9.Tehditler Karşısında Dayanıksızlıkla $\left(\mathrm{r}=-, 451^{* *} ; \mathrm{p}=0,000\right)$ negatif yönlü ilişkileri anlamlıdır.

Psikolojik Să̆lamlı̆̆ın 4.Diğerleri Yönelimlilik Şema Alanı alt ölçeği 12.Cezalandırılmayla (r= ,$\left.- 232^{*} ; \mathrm{p}=0,021\right)$ negatif yönlü ilişkileri anlamlıdır.

Psikolojik Sağlamlığın 5.Yüksek Standartlar ve Bastırılmışlık Şema Alanı alt ölçeği 13.Yüksek Standartlarla $\left(\mathrm{r}=-, 230^{*} ; \mathrm{p}=0,022\right)$ negatif yönlü ilişkileri anlamlıdır.

Psikolojik Să̆lamlığın 3.Zedelenmiş Sınırlar Şema Alanı alt ölçeği 10.Ayrıcalıklılık/Yetersiz Özdenetimle ( $\mathrm{r}=-0,116 ; \mathrm{p}=0,253)$, 4.Diğerleri Yönelimlilik Şema Alanı alt ölçeği 11.Kendini Fedayla ( $r=-0,048 ; p=0,635)$ ve 5.Yüksek Standartlar ve Bastırılmışlık Şema Alanı alt ölçeği 14.Onay Arayıcılıkla $(r=-0,082 ; p=0,418)$ ilişkileri istatistiksel olarak anlamlı bulunmamıştır.

Psikolojik sağlamlıkla arasında anlamlı ilişki bulunan uyumsuz şemaların psikolojik sağlamlığı yordaması için basit regresyon analizi yapılmış ve aşağıda sunulmuştur. Basit regresyon analizinin tercih edilmesinin nedeni, çoklu regresyonda yüksek ilişkisi olan yordayıcıların düşük ilişkisi olan yordayıcıları baskılayıp olası yordamaların bir kısmının göz ardı edilmesine kaynaklık etmesidir.

Tablo 8: Kopukluk Şema Alanı Alt Ölçeklerin Psikolojik Sağlamlığı Yordaması İçin Yapılan Basit Regresyon Analizi

\begin{tabular}{|c|c|c|c|c|c|c|c|c|c|c|c|c|}
\hline \multicolumn{2}{|l|}{ Yordayan } & \multirow{2}{*}{\multicolumn{5}{|c|}{ Regresyon Modeli }} & \multicolumn{6}{|c|}{ Kaysayı Tablosu } \\
\hline \multicolumn{2}{|c|}{ Young Şema Ölçeği Kısa Form-3 } & & & & & & \multicolumn{3}{|c|}{ Başlangıç değerler } & \multicolumn{3}{|c|}{$\begin{array}{l}\text { Standardize edilmiş } \\
\text { değerler }\end{array}$} \\
\hline $\begin{array}{l}\text { Üst Şema } \\
\text { Alanı }\end{array}$ & Alt Ölçek & $\mathbf{R}$ & $\mathbf{R}^{2}$ & $\mathbf{R}_{\text {che }}$ & $\mathbf{F}_{\text {che }}$ & $\mathbf{p}$ & Sabit & B & Sh & $\boldsymbol{\beta}$ & $\mathbf{t}$ & $\mathbf{p}$ \\
\hline \multirow{4}{*}{$\begin{array}{l}\text { Kopukluk } \\
\text { Şema } \\
\text { Alanı }\end{array}$} & $\begin{array}{l}\text { 1.Duygusal } \\
\text { Yoksunluk }\end{array}$ & ,342a & 0,12 & 0,11 & 12,88 &, $001 b$ & 25,02 & $-2,42$ & 0,67 & $-0,34$ & $-3,59$ & ,001 \\
\hline & $\begin{array}{l}\text { 2.Duyguları } \\
\text { Bastırma }\end{array}$ &, $323 \mathrm{a}$ & 0,10 & 0,10 & 11,29 &, $001 b$ & 24,68 & $-1,84$ & 0,55 & $-0,32$ & $-3,36$ & ,001 \\
\hline & $\begin{array}{l}\text { 3.Sosyal İzolasyon/ } \\
\text { Güvensizlik }\end{array}$ &, $333 \mathrm{a}$ & 0,11 & 0,10 & 12,10 &, $001 b$ & 25,02 & $-1,99$ & 0,57 & $-0,33$ & $-3,48$ & ,001 \\
\hline & 4.Kusurluluk &, $469 \mathrm{a}$ & 0,22 & 0,21 & 27,43 &, $000 \mathrm{~b}$ & 25,82 & $-3,00$ & 0,57 & $-0,47$ & $-5,24$ & 000 \\
\hline
\end{tabular}

Kopukluk Şema Alanı alt boyutu olan duygusal yoksunluk üzerinde Psikolojik Sağlamlığı yordama durumu için yapılan regresyon analizi sonucunda; Kopukluk Şema Alanı alt boyutu olan duygusal yoksunluk Psikolojik Sağlamlık durumunu negatif yönde yordadığ görülmektedir $\left(\mathrm{R}^{2}=0,12 ; \mathrm{p}<0,001\right)$. Kopukluk Şema Alanı alt boyutu olan duygusal yoksunluk Psikolojik Sağlamlık durumuna göre toplam varyansın \%12'sini açıkladığ gözlenmiştir.Duygusal Yoksunluk Şemasının psikolojik sağlamlığı negatif yönlü yordama gücü \%34 olarak tespit edilmiştir $(p=, 001 ; \beta=-, 34)$.

Diğer alt boyutlardan biri olan Duyguları Bastırma Şemasının psikolojik sağlamlığı yordaması için yapılan regresyon modeli $\mathrm{p}<0,01$ düzeyinde anlamlı bulunarak onaylanmıştır $\left(R_{\text {che }}=0,10\right.$; $\left.p=, 001^{b}\right)$. Modele göre psikolojik sağlamlık puanının \%10’u Duyguları Bastırma Şema puanıyla açıklanabilirken, Duyguları Bastırma Şemasının psikolojik sağlamlığı negatif yönlü yordama gücü \%32 olarak tespit edilmiştir $(p=, 001 ; \beta=-, 32)$.

Sosyal İzolasyon/ Güvensizlik Şemasının psikolojik sağlamlığı yordaması için yapılan regresyon modeli $\mathrm{p}<0,01$ düzeyinde anlamlı bulunarak onaylanmıştır $\left(R_{\text {che }}=0,10 ; p=, 001^{b}\right)$. Modele göre psikolojik sağlamlık puanının \%10’u Sosyal İzolasyon/ Güvensizlik Şema 
puanıyla açıklanabilirken, Sosyal İzolasyon/ Güvensizlik Şemasının psikolojik sağlamlığı negatif yönlü yordama gücü \%33 olarak tespit edilmiştir $(p=, 001 ; \beta=-, 33)$.

Kusurluluk Şemasının psikolojik sağlamlığı yordaması için yapılan regresyon modeli $\mathrm{p}<0,001$ düzeyinde anlamlı bulunarak onaylanmıştır $\left(R_{c h e}=0,21 ; p=, 000^{b}\right)$. Modele göre psikolojik sağlamlık puanının \%22'si Kusurluluk Şema puanıyla açıklanabilirken, Kusurluluk Şemasının psikolojik sağlamlığı negatif yönlü yordama gücü $\% 47$ olarak tespit edilmiştir $(p=, 000 ; \beta=-$ ,47).

Tablo 9: Zedelenmiş Otonomi Şema Alanı Alt Ölçeklerin Psikolojik Sağlamlığı Yordaması İçin Yapılan Basit Regresyon Analizi

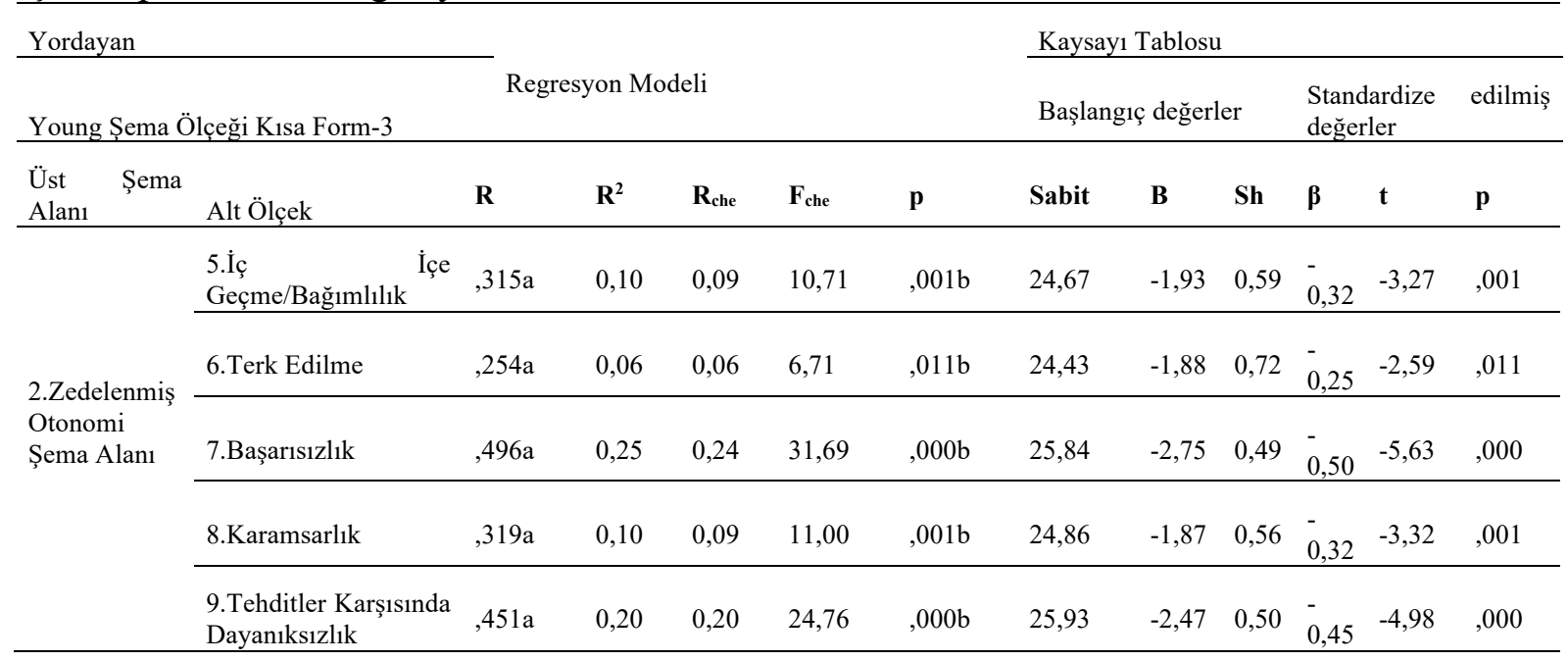

Zedelenmiş Otonomi Şema alt alanı olan İç İçe Geçme/Bağımlılık Şemasının psikolojik sağlamlığ 1 yordaması için yapılan regresyon modeli $\mathrm{p}<0,01$ düzeyinde anlamlı bulunarak onaylanmıştır $\left(R_{c h e}=0,09 ; p=, 001^{b}\right)$. Modele göre psikolojik sağlamlık puanının \%10'u İç İçe Geçme/Bağımlılık Şema puanıyla açıklanabilirken, İç İçe Geçme/Bağımlılık Şemasının psikolojik sağlamlığı negatif yönlü yordama gücü $\% 32$ olarak tespit edilmiştir $(p=, 001 ; \beta=-$ ,32).

Terk Edilme Şemasının psikolojik sağlamlığ yordaması için yapılan regresyon modeli $\mathrm{p}<0,05$ düzeyinde anlamlı bulunarak onaylanmıştır $\left(R_{c h e}=0,06 ; p=, 011^{b}\right)$. Modele göre psikolojik sağlamlık puanının \%6'sı Terk Edilme Şema puanıyla açıklanabilirken, Terk Edilme Şemasının psikolojik sağlamlığı negatif yönlü yordama gücü $\% 25$ olarak tespit edilmiştir $(p=, 011 ; \beta=-$ ,25).

Başarısızlık Şemasının psikolojik sağlamlığı yordaması için yapılan regresyon modeli $\mathrm{p}<0,001$ düzeyinde anlamlı bulunarak onaylanmıştır $\left(R_{c h e}=0,24 ; p=, 000^{b}\right)$. Modele göre psikolojik sağlamlık puanının \%25 Başarısızlık Şema puanıyla açıklanabilirken, Başarısızlık Şemasının psikolojik sağlamlığı negatif yönlü yordama gücü $\% 50$ olarak tespit edilmiştir $(p=, 000 ; \beta=-$ $, 50)$.

Karamsarlık Şemasının psikolojik sağlamlığ 1 yordaması için yapılan regresyon modeli $\mathrm{p}<0,01$ düzeyinde anlamlı bulunarak onaylanmıştır $\left(R_{c h e}=0,09 ; p=, 001^{b}\right)$. Modele göre psikolojik sağlamlık puanının \%10’u Karamsarlık Şema puanıyla açıklanabilirken, Karamsarlık Şemasının psikolojik sağlamlığı negatif yönlü yordama gücü \%32 olarak tespit edilmiştir $(p=, 001 ; \beta=-, 32)$. 
Tehditler Karşısında Dayanıksızlık Şemasının psikolojik sağlamlığı yordaması için yapılan regresyon modeli $\mathrm{p}<0,001$ düzeyinde anlamlı bulunarak onaylanmıştır $\left(R_{\text {che }}=0,20 ; p=, 000^{b}\right)$. Modele göre psikolojik sağlamlık puanının \%20'si Tehditler Karşısında Dayanıksızlık Şema puanıyla açıklanabilirken, Tehditler Karşısında Dayanıksızlık Şemasının psikolojik sağlamlığı negatif yönlü yordama gücü $\% 45$ olarak tespit edilmiştir $(p=, 000 ; \beta=-, 45)$

Tablo 10: Diğerleri Yönelimlilik Şema Alanı Alt Ölçeğinin Psikolojik Sağlamlığg Yordaması İçin Yapılan Basit Regresyon Analizi

\begin{tabular}{|c|c|c|c|c|c|c|c|c|c|c|c|c|}
\hline \multicolumn{2}{|l|}{ Yordayan } & \multirow{2}{*}{\multicolumn{5}{|c|}{ Regresyon Modeli }} & \multicolumn{6}{|c|}{ Kaysayı Tablosu } \\
\hline \multicolumn{2}{|c|}{ Young Şema Ölçeği Kısa Form-3 } & & & & & & Başlan & $1 c ̧$ değ & & $\begin{array}{l}\text { Standa } \\
\text { değerl }\end{array}$ & & edilmiş \\
\hline Üst Şema Alanı & Alt Ölçek & $\mathbf{R}$ & $\mathbf{R}^{2}$ & $\mathbf{R}_{\text {che }}$ & $\mathbf{F}_{\text {che }}$ & $\mathbf{p}$ & Sabit & B & Sh & $\boldsymbol{\beta}$ & $\mathbf{t}$ & $\mathbf{p}$ \\
\hline $\begin{array}{l}\text { 4.Diğerleri } \\
\text { Yönelimlilik Şema } \\
\text { Alanı }\end{array}$ & $\begin{array}{l}\text { 12. Cezalandı } \\
\text { rilma }\end{array}$ &, $232 \mathrm{a}$ & 0,05 & 0,04 & 5,52 &, $021 b$ & 24,23 & $-1,02$ & 0,43 & $-0,23$ & $\overline{2,35}$ & ,021 \\
\hline
\end{tabular}

Diğerleri Yönelimlilik Şema alt alanı olan Cezalandırılma Şemasının psikolojik sağlamlığı yordaması için yapılan regresyon modeli $\mathrm{p}<0,05$ düzeyinde anlamlı bulunarak onaylanmıştır $\left(R_{\text {che }}=0,04 ; p=, 021^{b}\right)$. Modele göre psikolojik sağlamlık puanının \%5'i Cezalandırılma Şema puanıyla açıklanabilirken, Cezalandırılma Şemasının psikolojik sağlamlığı negatif yönlü yordama gücü $\% 23$ olarak tespit edilmiştir $(p=, 021 ; \beta=-, 23)$.

Tablo 11: Yüksek Standartlar ve Bastırılmışlık Şema Alanı Alt Ölçeğinin Psikolojik Sağlamlığı Yordaması İçin Yapılan Basit Regresyon Analizi

\begin{tabular}{|c|c|c|c|c|c|c|c|c|c|c|c|c|}
\hline \multirow{2}{*}{\multicolumn{2}{|c|}{$\begin{array}{l}\text { Yordayan } \\
\text { Young Şema Ölçeği Kısa Form-3 }\end{array}$}} & \multirow{2}{*}{\multicolumn{5}{|c|}{ Regresyon Modeli }} & \multicolumn{6}{|c|}{ Kaysayı Tablosu } \\
\hline & & & & & & & \multicolumn{3}{|c|}{ Başlangıç değerler } & \multicolumn{3}{|c|}{ Standardize edilmiş değerler } \\
\hline Üst Şema Alanı & Alt Ölçek & $\mathbf{R}$ & $\mathbf{R}^{2}$ & $\mathbf{R}_{\text {che }}$ & $F_{\text {che }}$ & $\mathbf{p}$ & Sabit & B & Sh & $\beta$ & $\mathbf{t}$ & $\mathbf{p}$ \\
\hline $\begin{array}{l}\text { 5.Yüksek } \\
\text { Standartlar ve } \\
\text { Bastırılmışlık Şema } \\
\text { Alanı }\end{array}$ & $\begin{array}{l}\text { 13.Yüksek } \\
\text { Standartlar }\end{array}$ &, $230 \mathrm{a}$ & 0,05 & 0,04 & 5,43 &, $022 b$ & 23,92 & $-1,03$ & 0,44 & $-0,23$ & $-2,33$ & 022 \\
\hline
\end{tabular}

Yüksek Standartlar ve Bastırılmışlık Şema alt alanı olan Yüksek Standartlar Şemasının psikolojik sağlamlığı yordaması için yapılan regresyon modeli $\mathrm{p}<0,05$ düzeyinde anlamlı bulunarak onaylanmıştır $\left(R_{\text {che }}=0,04 ; p=, 022^{b}\right)$. Modele göre psikolojik sağlamlık puanının \%5'i Yüksek Standartlar Şema puanıyla açıklanabilirken, Yüksek Standartlar Şemasının psikolojik sağlamlığı negatif yönlü yordama gücü $\% 23$ olarak tespit edilmiştir $(p=, 022 ; \beta=-$ ,23).

\section{TARTIŞMA}

Araştırma sonuçlarına bakıldığında psikolojik sağlamlık düzeyinin cinsiyet ve yaş grubu gibi sosyo-demografik özellikler açısından anlamlı çıkmadığı görülmektedir. Alan yazı incelendiğinde, yapılan araştırmalar sonucunda bazı araştırmalarda cinsiyet dağılımı ile psikolojik sağlamlık düzeyi arasında anlamlı fark bulunurken (Aydın, 2010; Şahin, 2018 Kımter, 2020) ; bazı araştırmalarda anlamlı düzeyde fark bulunmamıştır (Aydın ve Egemverdiyeva, 2018; Özer, 2013; Terzi, 2008; Ülker Tümlü ve Recepoğl1, 2013). Toplumsal cinsiyet rollerini göz önüne bulundurduğumuzda; Türk toplumunda kadınların ve erkeklerin olaylara karşı bakış açıları ve gösterdikleri tepkilerin farklılık göstermesi erkeklerin psikolojik sağlamlık düzeylerinin kadınlara göre yüksek olmasını açıklayabilmektedir (Ülker Tümlü ve Recepoğlu, 2013). 
Araştırma sonucuna göre, medeni durum ile psikolojik sağlamlık arasında evliler lehine tespit edilmiştir. Alan yazı incelendiğinde, Bozgeyikli ve Şat (2014) ve Parmaksız (2020)'ın yapmış oldukları araştırmalarda da medeni durumun psikolojik sağlamlık puanlarını anlamlı derecede farklılaştırdığı sonucuna ulaşmıştır. Parmaksız (2020)'ın yapmış olduğu araştırmada psikoloji lisans bölümü mezunlarına yönelik gerçekleştirilmiş olup araştırma sonucunda katılımcıların psikolojik sağlamlık düzeyi orta olarak değerlendirilmektedir.

Aydın ve Egemdiyeva (2018) 'Üniversite Öğrencilerinin Psikolojik Sağlamlık Düzeylerinin İncelenmesi'ne yönelik yapmış oldukları araştırmada, ruh sağlığ 1 disiplinlerinde çalışanların, diğer disiplinlerde çalışanlara göre düşük psikolojik sağlamlık düzeyine sahip olduğu sonucuna ulaşmışlardır. Bu durumun nedeni, meslek yaşamı çerçevesinde alınan eğitimlerin, yaşam deneyimleri ve terapi süreçlerinin, ruh sağlığı alanında çalışan profesyonellerin tramvatik ya da stresli olaylara karşı farkındalığını artırmasından kaynaklanabileceği düşünülmüştür.

Önceden gelir getirici bir işte çalışma durumu ile psikolojik sağlamlık düzeyi arasında anlamlı bir ilişki bulunmamıştır. İlgili literatürde psikolojik sağlamlığa yönelik olarak yaşam deneyimi vb. değişkene ilişkin bir çalışmaya rastlanılmamıştır. 'Yaş' değişkeni göz önünde bulundurduğunda, yaş ile psikolojik sağlamlık düzeyinin anlamlı çıkmaması bu durum ile desteklenebilir.

Araştırmaya katılan bireylerin aile sistemi içerisindeki kaçıncı çocuk oldukları ile psikolojik sağlamlık düzeyi arasında anlamlı bir fark bulunmamaktadır. Alan yazı incelendiğinde, İlmen'in (2020) evli bireylerin psikolojik sağlamlık ve evlilik uyumlarına ilişkin araştırmasında psikolojik sağlamlık düzeyinin doğum sırasını yordadığı sonucuna ulaşılmıştır. Şahin'in (2018) yapmış olduğu araştırmada ailedeki kardeş sayısı ve sırası ile psikolojik sağlamlık arasında anlamlı bir pozitif yönde ilişki olmadığı görülmektedir. Oktan, Odacı ve Berber-Çelik' in (2011) üniversiteli öğrenciler ile yaptıkları araştırmaya göre, ilk ve en son doğan çocuğun psikolojik doğum sırasının psikolojik sağlamlık düzeyi ile negatif yönde; ortanca ve tek çocuk psikolojik doğum sırasının ise pozitif yönde ilişkili olduğu sonucuna ulaşmışlardır.

Doğum sırası arttıkça aile için yer alma, ilgi ve odağın paylaşılması gibi durumlar ortaya çıkmaktadır. Diğer doğum sıraları ile karşılaştırıldığında, doğumda en son dünyaya gelen çocuk, kişiler arası ilişsilerde en itaatkâr olan kişiler olarak ortaya çıkmaktadır (Kalkan ve Odacı, 2010). Bu çalışma sonucunu destekler nitelikte Bahadır'ın (2009) yaptığı çalışmada üniversite öğrencilerinin doğum sıralarının, psikolojik sağlamlıkları üzerinde istatiksel olarak anlamlı düzeyde etkisi olmadığı görülmektedir. Benzer şekilde, Klevens, Restepo ve Roca'nın (2000) genç yetişkinlerle yaptığ bir çalışmada, psikolojik sağlamlıklarının doğum sıralarına göre değişmediği sonucuna ulaşılmıştır. Bununla birlikte alanyazında yapılan bu araştırmanın sonuçlarıyla çelişen araştırma da (Ergüner-Tekinalp ve Terzi, 2014) bulunmaktadır. Kardeş sayısı değişkeninde vurgulandığı gibi, bu bulgunun elde edilmesinde de psikolojik danışmanların eğitimleri sürecinde kazandıkları değişimlerin etkili olduğu söylenebilir. $\mathrm{Bu}$ çerçevede aile içindeki göz bebeği olma durumundan dolayı sosyal çevrede uyum göstermek için kurallara bağlı kalmayı tercih etmesi ve sosyal çevrede sert bir sistem ile karşı karşıya kaldığında da olumsuzlukları kemikleştirmesi muhtemel bir davranıştır.

Erken dönem uyumsuz şemalar ile psikolojik sağlamlık arasındaki ilişkiye bakıldığında; Duygusal Yoksunluk, Duyguları Bastırma, Sosyal İzolasyon/Güvensizlik, Kusurluluk, İç İçe Geçme/Bağımlılık, Terk Edilme, Başarısızlık, Karamsarlık, Tehditler Karşısında Dayanıksızlık, Cezalandırılma, Yüksek Standartlar alt basamakları ile anlamlı çıkmıştır.

Duygusal Yoksunluk şema alt basamağı, kişinin beklendik durumdaki duygusal destek ihtiyacı ve arzusunun sosyal çevresinden tatmin edici boyutta karşılanamayacağına ilişkin beklentisidir. Kişinin ilgi, empati ve korunma yoksunluğu olarak 3 biçimde olabilir. Duygusal yoksunluk şema alt basamağına sahip kişilerin, aile içi iletişism ve etkileşimin az olduğu, kapalı sınırlara 
sahip aile ortamında yetişen bireyler olduğu gözlemlenmektedir. Kusurluluk/Utanç şema alt basamağı kişinin kendisini kusurlu, çevresi tarafından istenmeyen, sevilmeyen, kötü, değersiz olarak hissetmesine neden olur; önemli konularda fayda sağlayamayacağına ve fikirlerinin değer görmeyeceğine inanma duygusunu barındırır. Bu kusurlar kişisel (bencillik, öfke patlamaları, kabul edilemez cinsel arzular) ya da genel (itici fiziksel görünüş, sosyal beceriksizlik) olabilirler. Şemanın kökeninde reddedici ebeveyn tarzları bulunmaktadır. Sosyal İzolasyon/Yabancilaşma şema alt basamağ1, kişinin kendisini sosyal çevresi ve tüm sistemlerden soyutlayarak kendisini farklı görme; herhangi bir gruba ait olmama durumunu içerir. İç İçe Geçme/Bağımlılık şema alt basamağı, kişinin kendi gelişim ve bireyselleşmesini hiçe sayarak değer verdiği ya da toplum tarafından değer gören birine karşın aşırı derecede duygusal ilgi ve yakınlığı barındırır. Bu şemaya sahip kişiler, çevre alt sistemindeki kişilerin sürekli desteği ve ilgisi olmadan başarılı ya da mutlu olamayacaklarını düşünürler. Bu kişilerin kendilerine ait kimlik algısı olmayabilir. Terk edilme şema alt basamağı, kişinin önem ve değer verdiği çevre alt sistemine ilişkin olarak ihtiyaçlarının onlar tarafından karşılanamayacağı ve bundan dolayı zarar görecekleri algısını içerir. Bu şemaya sahip kişiler önem verdikleri kişilerin, duygusal olarak istikrarsız ve belirsiz, güvenilmez olduklarına ya da düzensizlik gösterdiklerine; yakında öleceklerine ya da daha iyi birisinden yana olup kendilerini terk edeceklerine inandıklarından dolayı onlardan duygusal destek, bağlantılılık, güç ya da pratik korunma sağlamaya devam edemeyecekleri duygusunu taşırlar. Bu şemaya sahip olan kişiler önemli diğerleriyle olan ilişkilerinin kalıcı olmayacağı inancına sahiptirler (Young,1994).

Başarısızlık alt şema basamağı, kişinin ortaya koyduğu performans ya da iş neticesinde başarısız olacağı, diğer kişilerle rekabet ortamında yetersiz kalacağı inancını içerir. Karamsarlık alt şema başmağına bakıldığında, yaşamın pozitif yönlerini değersiz kılarak, negatif yönlerine odaklanmayı içerir. Bu şema alt basamağı kişilerin genellikle olumlu yönde ilerleyen bir olaya yönelik er ya da geç olumsuz olacağına ilişkin beklentisini içerir. $\mathrm{Bu}$ bireylerin, olayların olumsuz gelişeceğine olan inançları nedeniyle genellikle kaygı düzeyleri yüksektir (Kömürcü,2014).

Tehditler Karşısında Dayanıksızlık şema alt basamağı, herhangi bir anda kesin bir felaket olacağına ve ondan korunamayacak olmaya ilişkin duyulan korkudur. Bu korkular tıbbi felaketlere yönelik olabileceği gibi duygusal ve dişsal felaketlere yönelik de olabilir.

Cezalandırıcılık alt şema basamağı, kişinin, olaylar çerçevesinde gerçekleştirdiği hatalar sonucunda, sahip olduğu alt sistemler tarafından cezalandırılacağı inancını içerir. Bu şema alt basamağına sahip kişiler genellikle kendilerine ve diğer insanlara karşı öfkeli ve hoşgörüsüzdürler (Young, 1994). İşlevsiz duygu düzenleme yoluyla erken uyumsuz şemalar, stres üreten mekanizmalardır ve strese karşı stratejilerin uygunsuz kullanımının arkasındaki nedenlerdir. $\mathrm{Bu}$ nedenle, çocukluk deneyimindeki duygusal ihtiyaçların karşılanamaması, işlevsel olmayan duygu düzenlemesinin ardından bir kişilik özelliği olarak düşük esnekliğin oluşmasına katkıda bulunmaktadır (Eberhart, Auerbach, Bigda-Peyton ve Abela, 2011). Bir bireyin stresli ve zararlı olaylara karşı dayanıklılığı azaldıkça, kırılganlık artmakta, bu da anksiyete ve depresyon belirtileri olasılığını artırmaktadır (Connor ve Davidson, 2003; Hjemdal ve ark., 2014).

Yüksek Standartlar/ Aşırı Eleştiricilik alt şema basamağına, kişilerin kendilerine yöneltilen eleştiriler karşında kaçınması ve benimsediği yüksek standartlara ilişkin olarak, bu standartlara erişmek ve bu standartları karşılamak için yoğun çaba göstermesi gerektiği inancını barındırır. $\mathrm{Bu}$ şemaya sahip kişiler hem kendilerine hem de başkalarına yönelik baskıcı ve eleştirel olabilmektedir. Şema, mükemmeliyetçilik, katı ahlaki, kültürel, dinsel kurallar ve daha fazlasını başarmak için zamana ve verimliliğe aşırı odaklanma olarak görülmektedir. Şemanın kökenine bakıldığında, yüksek standartlı ebeveynlerin içselleştirildiği ve kusurluluk şemasının aşırı telafisinin olduğu görülmektedir. 
Alanyazın incelendiğinde psikolojik sağlamlık düzeyi bireyin stresle uyum içerisinde yaşaması ile eşdeğerlik göstermektedir (Gizir, 2007). Şema alt basamakları dikkate alındığında bireyin kendinde oluşturduğu stresle yaşama uyum, yapmış olduğu işler karşısında çevreden onay araması ve çevresi ile kendinden ödün vererek uyum sağlama isteği gibi durumlar psikolojik sağlamlık olgusunu desteklemektedir.

Killgore, Taylor ve Cloonan (2020)'ın yaptığı çalışmada Covid-19 süreci ile birlikte bireylerin psikolojik sağlamlık düzeylerinin düştüğü ortaya çıkmıştır. Ortaya çıkan zorlayıcı yaşam koşulları ve belirsizlik süreçleri bireyin ruh sağlı̆̆ının korunmasında ve amaçladığı süreçlere ulaşmasında önemli etkisi olan psikolojik sağlamlık üzerine yapılan çalışmaların gerçekleştirilmesi ve araştırmalardan ortaya çıkan sonuçlar neticesinde hem tedavi edici hem de koruyucu önleyici müdahale yöntemlerinin ortaya konmasına ihtiyaç duyulmaktadır (Bozdă̆, 2020).

Rhein ve Sukawatana (2015)'nın 'Kaygı düzeyi ile ilişkili olabilecek erken dönem uyumsuz şemalar'a ilişkin yaptıkları araştırmada, üniversite öğrencilerinin farklı alanlarda maruz kaldıkları pek çok stres faktörünü; hastalıklar ve tehditlere karşı dayanıksızlık, terk edilme/istikrarsızlık ve karamsarlık/kötümserlik başta olmak üzere pek çok şemanın üniversite öğrencilerinin kaygı düzeyini yordadığını ortaya koymuşlardır. Zadahmad ve Torkan (2016)'ın üniversite öğrencilerine yönelik gerçekleştirdikleri araştırmalarında ise güvensizlik/suistimal edilme, hastalıklar ve tehditlere karşı dayanıksızlık ve sosyal izolasyon/yabancılaşma, kaygıyı yordayan şemalar olarak ortaya konmuştur.

\section{SONUÇ VE ÖNERILER}

Araştırmanın çalışma grubu İBB psiko-sosyal destek hattında çalışan psikologlar ile gerçekleştirilmiştir. Bu sebeple katılımcı sayısı görece az olarak değerlendirilebilir. İlgili konu farklı meslek grupları ile daha geniş katılımcı, süreç içerisinde online ya da yüz yüze terapi ya da danışmanlık hizmeti sunan meslek profesyonelleri ile gerçekleştirilebilir. Psikolojik sağlamlığı yordayan diğer psikopatolojilerle araştırma zenginleştirilebilir. Alan yazın ve toplum ruh sağlığı alanında yürütülen çalışmalar gözlemlendiğinde araştırma neticesinde kriz dönemlerinde toplum ruh sağlığı çalışanlarına yönelik etkin süpervizyon modellerinin geliştirilmesi ve tüm meslek elemanlarının kurumları tarafından sunulan kaynaklar çerçevesinde akademik süpervizyon ve akran etkileşimli süpervizyon çalışmaları ile desteklenmesi önerilmektedir.

Kopukluk Üst Şema Alanından Duygusal Yoksunluk, Duyguları Bastırma, Sosyal İzolasyon/ Güvensizlik ve Kusurluluk şemalarının; Zedelenmiş Otonomi Üst Şema Alanından İç İçe Geçme/Bağımlılık, Terk Edilme, Başarısızlık, Karamsarlık ve Tehditler Karşısında Dayanıksızlık şemalarının; Diğerleri Yönelimlilik Üst Şema Alanından Cezalandırılma şemasının ve Yüksek Standartlar ve Bastırılmışlık Üst Şema Alanından Yüksek Standartlar şemasının psikolojik sağlamlığı negatif yönlü yordamaları anlamlı bulunmuştur. Buna göre, bireydeki olumsuz şemaların puanı yükselirken bireyin psikolojik sağlamlığı düşmektedir denilebilir.

Psikolojik sağlamlığın cinsiyet, önceden bir işte çalışma durumu, fiziksel doğum sırası ve yaş grupları arasındaki farklılaşması istatistiksel olarak anlamlı bulunmuştur.Psikolojik sağlamlığın evlilerde bekarlardan anlamlı düzeyde yüksek olduğu tespit edilmiştir. Yapılan araştırma neticesinde psikolojik Sağlamlığın; Duygusal Yoksunlukla, Duyguları Bastırmamayla, Sosyal İzolasyon/Güvensizlikle, Kusurlulukla, İç İçe Geçme/Bağımlılıkla, Terk Edilmeyle, Başarısızlıkla, Karamsarlıkla, Tehditler Karşısında Dayanıksızlıkla, Cezalandırılmayla ve Yüksek Standartlarla arasında negatif yönlü anlamlı ilişkiler tespit edilirken; 
Ayrıcalıklılık/Yetersiz Özdenetimle, Kendini Fedayla ve Onay Arayıcılıkla ilişkileri istatistiksel olarak anlamlı bulunmamıştır.

\section{KAYNAKÇA}

Adıgüzel, C., Dümenci Bapoğlu, S. \& Topal, M. (2019). Çekingenlik Davranışının Tespiti ve Giderilmesine İlişkin Şema Yaklaşımı İle Büyük Ebeveyn - Ebeveyn ve Çocuk İlişkisi. Gelişim ve Psikoloji Dergisi (GPD), 1(1), 17-25.

American Psychological Association. (2014). The road to resilience. Washington: American Psychological Association. Erişim adresi http://www.apa.org/helpcenter/roadresilience.aspx.

Arden, M.A. \& Chilcot, J. (2020). Health Psychology And The Coronavirus (COVID-19) Global Pandemic: A Call For Research. British Journal of Helath Psychology, 25(2), 231232. doi.org/10.1111/bjhp.12414.

Aydın, B. (2010). Üniversite Ögrencilerinin Duygusal Zeka ve Umut Düzeyleri İle Psikolojik Sağlamlıkları Arasındaki İlişkinin İncelenmesi. (Yayınlanmamış Yüksek Lisans Tezi). Karadeniz Teknik Üniversitesi, Trabzon.

Aydın, M. \& Egemberdiyeva, A. (2018). Üniversite Öğrencilerinin Psikolojik Sağlamlık Düzeylerinin İncelenmesi. Türkiye Eğitim Dergisi, 3(1), 37-53.

Bahadır, E. (2009). Sağlıkla İlgili Fakültelerde Eğitime Başlayan Öğrencilerin Psikolojik Sağlamlık Düzeyleri. (Yüksek Lisans Tezi). Hacettepe Üniversitesi Sağlık Bilimleri Enstitüsü. Ankara.

Bilge, Y. ve Bilge, Y. (2020). Koronavirüs Salgını ve Sosyal İzolasyonun Psikolojik Semptomlar Üzerindeki Etkilerinin Psikolojik Sağlamlık Ve Stresle Baş Etme Tarzları Açısından İncelenmesi.Klinik Psikiyatri , 3(Ek 1), 38-51.

Bonanno, G. A., Galea, S., Bucciarelli, A., \&Vlahov, D. (2007). What Predicts Psychological Resilience After Disaster? The Role Of Demographics, Resources, And Life Stress. Journal of Consulting and Clinical Psychology, 75(5), 671-682.

Bozdağ, F. (2020). Pandemi Sürecinde Psikolojik Sağlamlık. Turkish Studies, 15(6), 247,257.

Bozgeyikli, H. \& Şat, A. (2014). Öğretmenlerde Psikolojik Dayanıklılık Ve Örgütsel Vatandaşlık Davranışlarının Bazı Değişkenler Açısından İ̉celenmesi: Özel Okul Örneği. HAK-ISS Uluslararası Emek ve Toplum Dergisi, 3 (5), 172-191.

Camara. M, ve Calvete, E. (2011). Early maladaptive schemas as moderators of the impact of stressful events on anxiety and depression in university students. Journal of Psychopathology and Behavioral Assessment, 34,58-68.

Calvete, E., Orue, I., ve Hankin, B. L. (2015). A Longitudinal Test Of The Vulnerability-Stress Model With Early Maladaptive Schemas For Depressive And Social Anxiety Symptoms İn Adolescents. Journal of Psychopathology and Behavioral Assessment, 37(1), 85-99. https://doi.org/10.1007/s10862-014-9438-x

Calvete, E., \& Camara, M. (2011). The Role Of Coping With Social Stressors In The Development Of Depressive Symptoms: Gender Differences. Anxiety, Stress \& Coping: An International Journal, 24(4), 387-406.

Connor, K. M., \& Davidson, J. R.T. (2003). Development Of A New Resilience Scale: The Connor-Davidson Resilience Scale (CD-RISC). Depression and Anxiety, 18(2), 76-82. https://doi.org/10.1002/da.10113

De Carlo, L. T. (1997), On The Meaning And Use Of Kurtosis. Psychological Methods, (2), 292-307.

Doğan, T. (2015). Kısa Psikolojik Sağlamlık Ölçeği'nin Türkçe Uyarlaması: Geçerlik Ve Güvenirlik Çalışması. Journal of Happiness \& Well-Being, 3:93-102. 
Dulmus, C. N. ve Hilarski, C. (2003). When stress constitutes trauma and trauma constitutes crisis: The Stress-Trauma-Crisis continuum. Brief Treatment and Crisis Intervention, 3(1), 27-35.

Eberhart, N. K., Auerbach, R. P., Bigda-Peyton, J., \& Abela, J. R. Z. (2011). Maladaptive Schemas And Depression: Tests Of Stress Generation And Diathesis-Stress Models. Journal of Social and Clinical Psychology, 30(1), 75-104. https://doi.org/10.1521/jscp.2011.30.1.75.

Ergüner Tekinalp, B., \& Terzi, Ş. (2012). Terapötik Bir Araç Olarak Bağışlama: İyileştirici Etken Olarakbağışlama Olgusunun Psikolojik Danışma Sürecinde Kullanımı. Eğitim Ve Bilim, 37(166), 14-24.

Fletcher, D., \& Sarkar, M. (2013). Psychological Resilience: A Review And Critique Of Definitions. Concepts, And Theory, 18(1), 12-23. https://doi.org/10.1027/10169040/a000124

Folkman, S., Lazarus, R.S., Pimley, S. ve diğ. (1987). Age Differences İn Stress And Coping Processes. Psychology and Aging, 2(2), 171-184.

George, D. \& Mallery, P. (2010). SPSS For Windows Step By Step: A Simple Guide And Reference 17.0 Update (10th Edition). Boston: Allyn ve Bacon.

Gizir, CA. (2007). Psikolojik Sağlamlık, Risk Faktörleri Ve Koruyucu Faktörler Üzerine Bir Derleme Çalışması. Türk Psikolojik Danışma ve Rehberlik Dergisi, 3, 113-128.

Gör, N., Yiğit, İ., Kömürcü, B. \& Şenkal Ertürk, İ. (2017). Geçmişin Mirası Ve Geleceğin Haritas1: Erken Dönem Uyumsuz Şemalar. Nesne, 5(10), 197-217.

Groeneveld, R. A., \& Meeden, G. (1984), Measuring skewness and kurtosis. The Statistician, (33), 391-399.

Hjemdal, O., Hagen, R., Ottesen Kennair Leif, E., Solem, S., Wells, A., Nordahl, H. (2014). Resilience and metacognitions as predictors of outcome in a randomized controlled treatment trial of generalized anxiety disorder. In MEDIMOND. Proceedings of the Second World Congress on Resilience: From Person to Society (Ed S Ionescu), 1083. May 8-10 2014, Timisoara, Romania.

Huber M., Knottnerus A.J., \& Green L. (2011). How should we define health?. BMJ, 343 doi.org/10.1136/bmj.d4163.

Hortaçsu, N. (2003). İnsan ilişkileri. Ankara: İmge Kitapevi.

İlmen, Z. (2020). Evli Bireylerin Psikolojik Doğum Sirası, Evlilik Uyumu Ve Psikolojik Sağlamlıkları Arasındaki Yordayıcı İlişkiler. (Yayımlanmamış yüksek lisans tezi), Selçuk Üniversitesi, Konya.

Kalkan, M., \& Odacı, H. (2010). Psikolojik Doğum Sırası Ve Ana Babaya Bağlanma: Okul Öncesi Öğretmen Adayları Üzerine Bir Çalışma . Education Sciences , 5 (3) , 810-819.

Karasar, N. (2014). Bilimsel Araştırma Yöntemi. (26.baskı). Ankara Nobel Yayınevi.

Kavi, E. \& Karakale, B. (2018). Çalışan Psikolojisi Açısından Psikolojik Dayanıklılık. HAK-íŞ Uluslararası Emek ve Toplum Dergisi, 7(17): 55-77. DOI: 10.31199/hakisderg.391826.

Kent M., Davis C.M. \& Reich J.W. (Ed.).(2013). The Resilience Handbook 'Approaches to Stress and Trauma'. New York, Routledge.

Keyes M.L. (2009). Risk and Resilience in Human Development: An Introduction. Research in Human Development. 1(4). 223-227. doi.org/10.1207/s15427617rhd0104_1.

Khademi, M.H. ve Sabbaghi, R.S. (2017). Comparison between Three Types of Ammonia Synthesis Reactor Configurations in Terms of Cooling Methods. Chemical Engineering Research and Design, 128, 306-317. doi.org/10.1016/j.cherd.2017.10.021.

Kımter, N. (2020). Covid-19 Günlerinde Bireylerin Psikolojik Sağlamlık Düzeylerinin Bazı Değiş̧kenler Açısından İncelenmesi. IBAD Sosyal Bilimler Dergisi, 2020; (Özel Sayı): 574-605 DOI: 10.21733/ibad.805481. 
Killgore, W. D. S., Taylor, E. C., ve Cloonan, S. A. (2020). Psychological resilience during the COVID-19 lockdown. Psychiatry Research, 291, 113216. https://doi.org/10.1016/j.psychres.2020.113216.

Klevens, J., Restrepo, O. \& Roca, J.( 2000) .Some Factors for Explaining Resilience Among Young Men in Colombia. Rev. salud pública [online], 2(2), 165-172. ISSN 0124-0064.

Kömürcü B. (2014). Erken Dönem Uyumsuz Şemalar, Ebeveynlik Biçimleri Ve Psikolojik Belirtiler İle Psikolojik Dışlanmanın Tehdit Ettiği İhtiyaçlar Arasındaki İlişkiler. (Yaynınlanmamış Yüksek Lisans Tezi). Hacettepe Üniversitesi Sosyal Bilimler Enstitüsü. Ankara.

Liu, N., Zhang, F., Wei, C., Jia, Y., Shang, Z., Sun, L., Wu, L., Sun, Z., Zhou, Y., Wang, Y., \& Liu, W. (2020). Prevalence and predictors of PTSS during COVID-19 outbreak in China hardest-hit areas: gender differences matter. Psychiatry Res. ;287 doi: 10.1016/j.psychres.2020.112921.

Lumley, M. N., \& Harkness, K. L. (2007). Specificity in the relations among childhood adversity, early maladaptive schemas, and symptom profiles in adolescent depression. Cognitive Therapy and Research, 31(5), 639-657. https://doi.org/10.1007/s10608-0069100-3.

Moors, J. J. A. (1986). The Meaning Of Kurtosis: Darlington Reexamined. The American Statistician, (40), 283-284.

Oktan, V., Odacı, H., ve Berber-Çelik, Ç. (2014). Psikolojik Doğum Sırasının Psikolojik Sağlamlığın Yordanmasındaki Rolünün İncelenmesi. Abant İzzet Baysal Üniversitesi Eğitim Fakültesi Dergisi, 14(1), 140-152.

Örücü, E. \& Boz, H. (2014). Konaklama İşletmelerinde İşe Alıştırma Eğitiminin Örgütsel Bağlllı̆̆a Etkisi. Yönetim ve Ekonomi, 21(1). 61-76

Öz, F. \& Yılmaz E.B. (2009). Ruh Sağlığının Korunmasında Önemli Bir Kavram: Psikolojik Sağlamlık. Hacettepe Üniversitesi Hemşirelik Fakültesi Dergisi, 16(3). 82-89.

Özer, E. (2013). Üniversite Öğrencilerinin Psikolojik Să̆lamlık Düzeylerinin Duygusal Zeka Ve Beş Faktör Kişilik Özellikleri Açısından Incelenmesi. (Yayınlanmamış Doktora Tezi), Necmettin Erbakan Üniversitesi Eğitim Bilimleri Enstitüsü, Konya.

Parmaksız, İ. (2020). İyimserlik, Özgecilik ve Medeni Durumun Psikolojik Dayanıklılık Üzerindeki Etkileri. Pamukkale Üniversitesi Ĕ̈itim Fakültesi Dergisi, 48(-), 285 - 302.

Rhein, D. \& Sukawatana, P. (2015). Thai University Student Schemas And Anxiety Symptomatology. International Education Studies, 8(7), 108-126.

Roberts, A. R. (2005). Bridging The Past And Present To The Future Of Crisis İntervention And Crisis Management. In A. R.Roberts (Ed.), Crisis intervention handbook: Assessment, treatment, and research (3rd ed., pp. 3-34). New York: Oxford University Press.

Rutter, M. (2006). Implications Of Resilience Concepts For Scientific Understanding. Annals New York Academy of Sciences, 1094(1), 1-12.

Smith, B. W., Tooley, E. M., Christopher, P., \& Kay, V. S. (2010). Resilience As The Ability To Bounce Back: A Neglected Personal Resource?. Journal of Positive Psychology, 5, 166-176.

Soygüt, G., Karaosmanoğlu, A. ve Çakır, Z. (2009). Erken Dönem Uyumsuz Şemaların Değerlendirilmesi: Young Şema Ölçeği Kısa Form-3'ün Psikometrik Özelliklerine İlişkin Bir İnceleme. Türk Psikiyatri Dergisi, 20(1):75-84.

Şahin, S. (2018). Yaşam Deneyimlerinin Yetişkinlerdeki Benlik Saygısı, Psikolojik Sağlamlık ve Hayata Verilen Anlam Ile İlişkisi. (Yüksek Lisans Tezi). Kocaeli Üniversitesi Sağlık Bilimleri Enstitüsü. Kocaeli. 
T.C. Milli Eğitim Bakanlığı (2020). Salgın dönemlerinde psikolojik sağlı̆̆ımızı korumak. Ankara: Özel Eğitim ve Rehberlik Hizmetleri Genel Müdürlüğü. 3 Mayıs 20202 tarihinde http://www.meb.gov.tr/meb_iys_dosyalar/2020_03/30112459_ailecocuk.pdf adresinden erişildi.

Terzi, Ş. (2008). Üniversite Ögrencilerinin Kendini Toparlama Gücünün İçsel Koruyucu Faktörlerle İlişkisi. Hacettepe Üniversitesi Egitim Fakültesi Dergisi, 35, 297-306.

Traş, Z.ve Aydın, E.( 2019). Üniversite öğrencilerinde benlik saygısı ile kendini toparlama gücü arasındaki ilişkinin incelenmesi. Necmettin Erbakan Üniversitesi, Ereğli Eğitim Fakültesi Dergisi, 1(2), 71-78.

Ülker Tümlü, G. ve Recepoğlu, E., (2013). Üniversite Akademik Personelinin Psikolojik Dayanıklılık ve Yaşam Doyumu Arasındaki İlişki. Yükseköğretim ve Bilim Dergisi, 3(3), 205-213.

Vella, C.S-L ve Pai, B.N. (2019). A Theoretical Review of Psychological Resilience: Defining

Resilience and Resilience Research over the Decades. Archives of Medicine and Health Sciences, 7(2), 233-239.

Young, J.E., Klosko J.S., \& Weishaar, E.M. (2003). Şema Terapi (Çev. TV Soylu), İstanbul:Litera.

Young, J.E., \& Klosko, J.S. (2013). Hayatı Yeniden Keşfedin. (Çev. Ed.:H.A. Karaosmanoğlu, E. Tuncer). 3.basim, İstanbul:Psikonet.

Young, J. E. (1994). Cognitive Therapy For Personality Disorders: A Schema-Focused Approach. Sarasota: Professional Resource.

Zadahmad, M. \& Torkan, H. (2016). Investigation Of The Multiple Relationships Between Early Maladaptive Schemas And Coping Styles With Anxiety. International Journal of Educational and Psychological Researches, 2(1), 49-53 